Yves Lequin (Lyon) presented the results of his research on the effects of industrialization in the region Lyon-St. Etienne. His paper "La classe ouvrière française au XIXe siècle: une où multiple?" focused on the connection between regional mobility and organizational behavior. Of special interest was his thesis, supported by a wealth of material, that neither mobility between rural and urban regions, nor between different branches or even business cycles negatively influenced the organizational behavior of workers in this region.

Rudolf Vetterli (Zürich) spoke on "Social structure, work process, and organizational behavior of Swiss workers: The case of the Georg Fischer AG". In this case study of a foundry, Vetterli sshowed the influence of production techniques, changes in the work process and recruitment on the formation of a working class consciousness and the organizational behavior of workers.

In a final session several research projects were presented and discussed: Jürgen Kocka (Bielefeld), "Social Mobility and Marriage Patterns of Bielefeld Workers in the Nineteenth Century"; Hermann Schäfer (Freiburg), "The Workers of the Machine Factory André Koechlin \& Cie in Muhlhouse 1826-1875"; Klaus Tenfelde (Munich), "Stabilization and Destabilization of the Labor Potential during the Industrial Revolution"; Marhild von Behr (Munich), "The History of Apprentice Training in German Industry"; Dieter Langewiesche (Würzburg), "A Social History of the Working Class in the Weimar Republic".

\author{
Prof. Dr. Hartmut Kaelble \\ and Dr. Hermann J. Rupieper, \\ Freie Universität, Berlin
}

\title{
REPORT ON THE FIRST INTERNATIONAL SYMPOSIUM ON THE PROBLEMS OF MIGRATORY WORKERS FROM MEXICO AND THE UNITED STATES
}

The First International Symposium on the Problems of Migratory Workers from Mexico and the United States was held at the University of Guadalajara. Guadalajara, Mexico, between July 11-14. 1978. The Symposium was sponsored by the University of Guadalajara and the University of California, Los Angeles. It was organized by Enrique Zembrano Villa, Rector of the University of Guadalajara; Lic. Hugo Tulio Mendez, Director of the journal Mexico Agrario; and Dr. Juan GomezQuiñones, Director of the Chicano Studies Center at UCLA. Over thirty universities participated, representing faculty from Mexico, Latin America, the United States, and Europe.

The Symposium was divided into four topics of discussion with each day focusing on one of the following: (1) Agrarian problems and the generation of migratory field workers in Mexico; (2) Patterns of migration of field workers in Mexico; (3) Problems on the Mexican-United States border; and (4) Chicanos and Mexicans in the United States. A unifying theme emerged as both panelists and audience participation (over 2,000 attended the Symposium) repeatedly turned to the problem of the rights and welfare of migratory workers in the United States and Mexico.

One of the expected results of the Symposium was to provide a forum for future scholarly exchange among individuals and institutions. Since almost sixty papers and commentaries were presented, it is impossible to accurately and fairly abstract the diverse contributions of the panelists. However, 
there are a limited number of Xerox copies of the Symposium proceedings available for purchase through the

\author{
Publications Unit \\ Chicano Studies Center \\ University of California \\ Los Angeles, 'California 90024
}

or they can be ordered by calling (213) 825-2642.

Mauricio Mazón

University of Southern California

\title{
ANNOUNCEMENTS
}

The Study Group in American and International Working Class will sponsor a fraternal meeting at the annual meetings of the American Historical Association in San Francisco. The session is scheduled for December 28, 1978, 5-7 pm in the Lassen Room in the Hilton. The meeting will fea. ture a panel discussion on recent work and trends in European and American labor history led by John H. M. Laslett and David Brody, among others, to be followed by a Business Meeting. The Business Meeting will focus on future directions for the Study Group and the prospects for continuing $I L W C H$. Please attend if you are able; we are at a crossroad and we need the active involvement of members and interested historians.

The annual meeting of the Southwest Labor Studies Conference will be held at California Srate University, Dominguez Hills, at the end of April, 1979. To obtain final data and further information, write to Professor Will Scoggins, El Camino College, Torrance, California 90506.

At the 13th Conference of historians of the labor movement "Historische Modernisierungsforschung" held in Linz, Austria, from September 20-24, 1977, 120 people participated from 20 countries. Printed minutes of the proceedings can be ordered for Austrian Shillings 150.00 each. The 14th Conference in Linz (September 12-26, 1978) had a single topic: "Women in the Socialist Labor Movement 1900-1939". For the 15th Conference in Linz. 1979, the following subject has been suggested: "Social and Political Changes in the World at the End of the First World War and the Labor Movement". For further information, write to:

Internationale Tagung der Historiker der Arbeiterbewegung

1010 Wien

Altes Rathaus, Wipplingerstr. 8

Austria 